\title{
The deletion mutant EGFRvIll significantly contributes to stress resistance typical for the tumour microenvironment
}

\author{
Citation for published version (APA):
}

Theys, J., Jutten, B., Dubois, L. J., Rouschop, K. M. A., Chiu, R. K., Li, Y., Paesmans, K., Lambin, P., Lammering, G., \& Wouters, B. G. (2009). The deletion mutant EGFRvill significantly contributes to stress resistance typical for the tumour microenvironment. Radiotherapy and Oncology, 92(3), 399-404. https://doi.org/10.1016/j.radonc.2009.06.017

Document status and date:

Published: 01/09/2009

DOI:

10.1016/j.radonc.2009.06.017

Document Version:

Publisher's PDF, also known as Version of record

\section{Document license:}

Taverne

\section{Please check the document version of this publication:}

- A submitted manuscript is the version of the article upon submission and before peer-review. There can be important differences between the submitted version and the official published version of record.

People interested in the research are advised to contact the author for the final version of the publication, or visit the DOI to the publisher's website.

- The final author version and the galley proof are versions of the publication after peer review.

- The final published version features the final layout of the paper including the volume, issue and page numbers.

Link to publication

\footnotetext{
General rights rights.

- You may freely distribute the URL identifying the publication in the public portal. please follow below link for the End User Agreement:

www.umlib.nl/taverne-license

Take down policy

If you believe that this document breaches copyright please contact us at:

repository@maastrichtuniversity.nl

providing details and we will investigate your claim.
}

Copyright and moral rights for the publications made accessible in the public portal are retained by the authors and/or other copyright owners and it is a condition of accessing publications that users recognise and abide by the legal requirements associated with these

- Users may download and print one copy of any publication from the public portal for the purpose of private study or research.

- You may not further distribute the material or use it for any profit-making activity or commercial gain

If the publication is distributed under the terms of Article $25 \mathrm{fa}$ of the Dutch Copyright Act, indicated by the "Taverne" license above, 


\title{
The deletion mutant EGFRvIII significantly contributes to stress resistance typical for the tumour microenvironment
}

\author{
Jan Theys ${ }^{\mathrm{a}, *}$, Barry Jutten ${ }^{\mathrm{a}}$, Ludwig Dubois ${ }^{\mathrm{a}}$, Kasper M.A. Rouschop ${ }^{\mathrm{a}}$, Roland K. Chiu ${ }^{\mathrm{b}}$, Younan $\mathrm{Li}^{\mathrm{a}}$, \\ Kim Paesmans ${ }^{\text {, }}$, Philippe Lambin ${ }^{\text {, }}$ Guido Lammering ${ }^{\text {a, }}{ }^{\text {, Bradly G. Wouters }}{ }^{\text {a,c,d, } 1}$ \\ ${ }^{a}$ Maastricht Radiation Oncology (MaastRo) Lab, Grow-School for Oncology and Developmental Biology, University of Maastricht, The Netherlands \\ ${ }^{\mathrm{b}}$ Department of Health Risk Analysis and Toxicology, Maastricht University, The Netherlands \\ c Ontario Cancer Institute, Princess Margret Hospital, University Health Network, Departments of Radiation Oncology and Medical Biophysics, University of Toronto, Canada \\ ${ }^{\mathrm{d}}$ Selective Therapeutics Program, Ontario Institute for Cancer Research, Toronto, Canada
}

\section{A R T I C L E I N F O}

Article history:

Received 23 April 2009

Received in revised form 10 June 2009

Accepted 24 June 2009

Available online 16 July 2009

\section{Keywords:}

Epidermal growth factor receptor (EGFR)

EGFRvIII

Tumour

Microenvironment

Hypoxia

\begin{abstract}
A B S T R A C T
Background and purpose: The epidermal growth factor receptor (EGFR) is overexpressed or mutated in many tumour types. The truncated, constitutively active EGFRvIII variant has not been detected in normal tissues but is found in many malignancies. In the current study, we have investigated the hypothesis that EGFRvIII contributes to a growth and survival advantage under tumour microenvironment-related stress conditions.

Materials and methods: U373MG doxycycline-regulated isogenic cells expressing EGFRwt or EGFRvIII were created and validated using Western blot, FACS and qRT-PCR. In vitro proliferation was evaluated with standard growth assays. Cell survival was assayed using clonogenic survival. Animal experiments were performed using NMRI-nu-xenografted mice.

Results: Inducible isogenic cell lines were created and showed high induction of EGFRwt and EGFRvIII upon doxycycline addition. Overexpression of EGFRvIII but not of EGFRwt in this model resulted in a growth and survival advantage upon different tumour microenvironment-related stress conditions in vitro. Induction of EGFRvIII increased tumour growth in vivo, which was reversible upon loss of expression.

Conclusions: Under conditions where nutrients are limited and stress is apparent, as in the tumour microenvironment, expression of EGFRvIII leads to a growth and survival advantage. These data indicate a potential selection of EGFRvIII-expressing tumour cells under such stress conditions.
\end{abstract}

(c) 2009 Elsevier Ireland Ltd. All rights reserved. Radiotherapy and Oncology 92 (2009) 399-404
The epidermal growth factor receptor (EGFR) is overexpressed, amplified or altered in various human epithelial tumours [1]. Upon ligand binding and receptor activation, tyrosine residues in their cytoplasmatic domain are phosphorylated, resulting in the activation of downstream substrates that control cell proliferation, differentiation and survival. It is therefore not surprising that overexpression of EGFR has been shown to be associated with tumour aggressiveness and treatment resistance $[2,3]$ and that targeting of EGFR is a potentially promising treatment strategy [4-8].

Several reports have documented rearrangements within the EGFR gene, especially in primary glioblastomas [9]. The most common variant is EGFRvIII, which harbours an in-frame deletion resulting in a truncated receptor that lacks 267 amino acids in the extracellular binding domain. This truncation leads to impor-

\footnotetext{
* Corresponding author. Address: Maastricht Radiation Oncology (MAASTRO), GROW - School for Oncology and Developmental Biology, Uns 50/23, P.O. Box 616, Maastricht University, 6200 MD Maastricht, The Netherlands.

E-mail address: jan.theys@maastro.unimaas.nl (J. Theys).

1 These authors contributed equally to this work.
}

tant functional changes: the receptor cannot bind ligand, but is constitutively active, resulting in uncontrolled pro-oncogenic effects, thereby promoting neoplastic transformation and tumourigenicity. The EGFRvIII variant is found in many malignancies, including breast, head and neck, prostate, lung and brain tumours. In patients with glioblastoma, the EGFRvIII mutation has an overall prevalence of $50-60 \%$ in patients whose tumours show amplification of EGFR [10]. Strikingly, EGFRvIII has not been detected in normal tissues. Moreover, expression in tumour tissues in vivo is rapidly lost when cultured in vitro [11]. This observation suggests that the tumour microenvironment, which is characterized by heterogeneities in nutrient supply and oxygenation, may provide suitable conditions for growth and survival of EGFRvIII-expressing tumour cells. The establishment of such a microenvironment, unlike that of any normal tissue, is a consequence of alterations in the metabolic and proliferative status of tumour cells together with a highly irregular vascular supply [12]. This process is believed to occur early in the development of a tumour, and has been implicated in promoting metastasis, angiogenesis and increased malignancy. Cellular adaptive responses to this environment are 
critical for the continued growth of tumours. The role of EGFRvIII expression in the context of the tumour microenvironment has only been minimally defined. The present study was performed to investigate the contribution of EGFRvIII expression on tumour growth, as well as its importance in determining the response to microenvironmental stress.

\section{Materials and methods}

\section{Plasmids and generation of cell lines}

The glioblastoma cell line U373MG (ATCC, Manassas, VA, USA) was cultured in MEM $\alpha$ medium, supplemented with $10 \%$ FBS. Isogenic cell lines that can be induced to express either EGFR wildtype (wt) or EGFRvIII were generated using the Flp-In T-Rex Core Kit from Invitrogen (Breda, NL), according to the manufacturer's recommendations. These cell lines were designated U373FlpIn/ EGFRvIII and U373FlpIn/EGFRwt, respectively. To induce gene expression, doxycycline $(1 \mu \mathrm{g} / \mathrm{ml})$ was added to the medium.

\section{Antibodies and Western blotting}

Western blotting was done according to standard protocols as described [13]. Antibodies used were Sc-03 (Santa Cruz Biotechnology, Huissen, NL) for EGFRwt, L8A4 (a gift from D. Bigner, Duke University, Durham, NC, USA) for EGFRvIII and HRP-linked antirabbit (EGFRwt) or anti-mouse (EGFRvIII) secondary antibodies. Immobilized proteins were detected using ECL-plus reagent (Kirkegaard \& Perry Laboratories, NL) and by exposing blots to X-ray film.

\section{Quantitative real-time PCR}

RNA extraction was performed using the SV Total RNA Isolation System (Promega Corporation, Madison, WI, USA). cDNA was prepared using the iScript cDNA Synthesis kit (BioRad Laboratories, CA, USA). Reactions were carried out in a $25 \mu$ l volume using SYBR Green Master Mix (Applied Biosystems, CA) with the ABI Prism 7700 Sequence Detection System. Values for each gene were normalized to expression levels of $18 \mathrm{~S}$ RNA. The primer sequences used were:

EGFRvIII forward: 5'AAGAAAGGTAATTATGTGGTGACA3'; EGFRvIII reverse: 5'CCGTCTTCCTCCATCTCATAGC3'; EGFRwt forward: 5'ACCTGCGTGAAGAAGTGTCC3'; and EGFRwt reverse: 5'CCGTCTTCCTCCATCTCATAGC3'.

\section{Flow cytometric analysis}

FACS analysis with Oregon Green-labeled cetuximab was performed as described [14].

\section{In vitro growth and survival assays}

For growth under control aerobic conditions, $2.5 \times 10^{5}$ cells were seeded and incubated in $5 \% \mathrm{CO}_{2}$ for 1-7 days. To monitor growth under stress conditions, cells were seeded and allowed to attach during overnight incubation in $5 \% \mathrm{CO}_{2}$. The following day (day 0 ), dishes were placed in the hypoxic chamber or medium was replaced according to the appropriate conditions. Total cell numbers were counted after trypsinization using a Coulter $Z$ series particle counter (Beckman, Mijdrecht, NL) and cell numbers normalized to the amount of cells present at day 0. Clonogenic assays were performed as previously described [13].

\section{Tumour xenograft model}

In vivo experiments were performed using adult NMRI-nu (nu/ nu) female mice. Animal facilities and experiments were in accordance with local institutional guidelines. U373 FlpIn/EGFRvIII cells were mixed with matrigel and $3 \times 10^{6}$ cells were subcutaneously injected in the lateral flank. Induction of gene expression was done by giving animals doxycycline $(2 \mathrm{~g} / \mathrm{l})$ in their drinking water. Tumours were measured with calipers in 3 orthogonal diameters and volumes calculated with the formula $A \times B \times C \times \pi / 6$. The tumour doubling time $\left(T_{\mathrm{d}}\right)$ was calculated using the equation $T_{\mathrm{d}}=\left(T-T_{0}\right) \times \log 2 /\left[\log (V)-\log \left(V_{0}\right)\right]$ where $T-T_{0}$ indicates the length of time between two measurements and $V_{0}$ and $V$ denote the tumour volume at two points of measurement.

\section{Statistics}

Statistical analysis was carried out using the program GraphPad Prism version 5.01 for Windows (GraphPad Software, 2007, CA, USA). A Mann-Whitney $U$ test was used to assess differences in tumour doubling times. Non-linear regression analysis was performed to compare differences between in vivo growth curves. Student's $t$-test was applied to determine differences in growth and survival assays.

\section{Results}

To investigate the potential influence of EGFRvIII on tumour phenotype, and to compare the effect of EGFRvIII overexpression with that of EGFRwt, we created doxycycline-inducible U373MG glioma isogenic cell lines expressing EGFRvIII or EGFRwt. The unmodified parental U373MG cells express moderate levels of endogenous EGFRwt and have been widely recognized as a valuable in vitro and xenograft model. Previously, we constructed a Flp-In T-Rex host acceptor cell line, designated U373FlpIn. Following transfection and selection, we identified clones for both EGFRvIII and EGFRwt. Quantitative PCR revealed induction of mRNA levels of $7.15 \pm 0.6$ for EGFRvIII and $7.55 \pm 0.6$ for the EGFRwt in response to doxycycline (Fig. 1A). As shown in Fig. 1B, protein levels of EGFRvIII were strongly induced after exposure to doxycycline, with virtually undetectable background levels. EGFRwt is also induced in the U373FlpIn/EGFRwt cells, but to a lesser extent than EGFRvIII in the U373FlpIn/EGFRvIII cells, presumably due to the already expressed endogenous EGFRwt levels in U373FlpIn. To show that the vIII mutant and the wt receptor were properly processed and located at the cell membrane after doxycycline administration, we performed a flow cytometry experiment using Oregon Greenlabeled cetuximab (C225-OG) (Fig. 1C). Without doxycycline induction, both cell lines showed similar levels of C225-OG binding, indicating binding of C225-OG to endogenous EGFRwt receptor. Increased C225-OG binding was observed when doxycycline was added, reaching a 5- to 6-fold increase at $72 \mathrm{~h}$. Taken together, these data demonstrate that the use of this inducible system is feasible and that it results in an increase of correctly processed receptors at the membrane of induced U373FlpIn cells.

To assess the biological relevance of EGFRvIII expression in relation to stress typically found in the tumour microenvironment, we evaluated the growth of U373FlpIn/EGFRvIII and U373FlpIn/ EGFRwt inducible isogenic cell lines under conditions of serum starvation, low $\mathrm{pH}$, glucose deprivation, hypoxia $(0.2 \%)$ and anoxia. As shown in Fig. 2, no effect on growth after induction of EGFRvIII or EGFRwt was observed in medium containing 10\% FBS. However, in conditions of serum starvation, addition of doxycycline to overexpress EGFRvIII resulted in a consistent growth advantage over non-induced cells (Fig. 2A). In contrast, no proliferation effect 
A

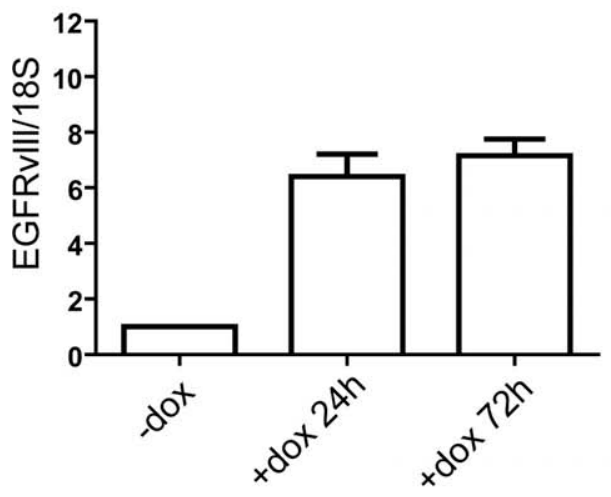

B

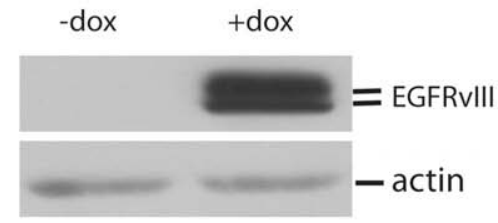

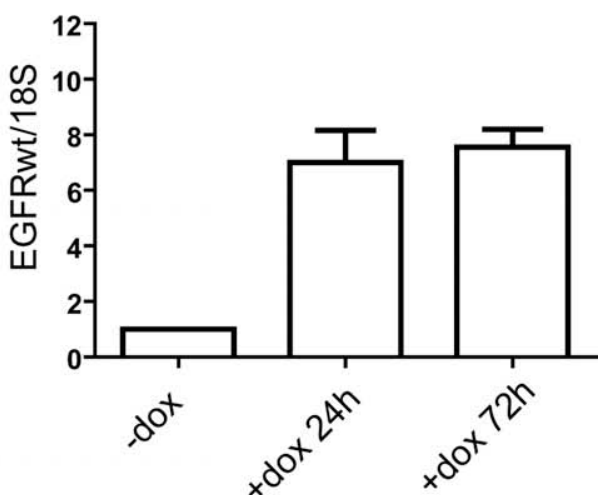

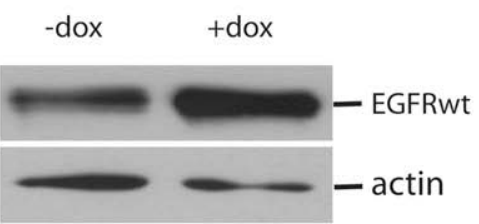

C
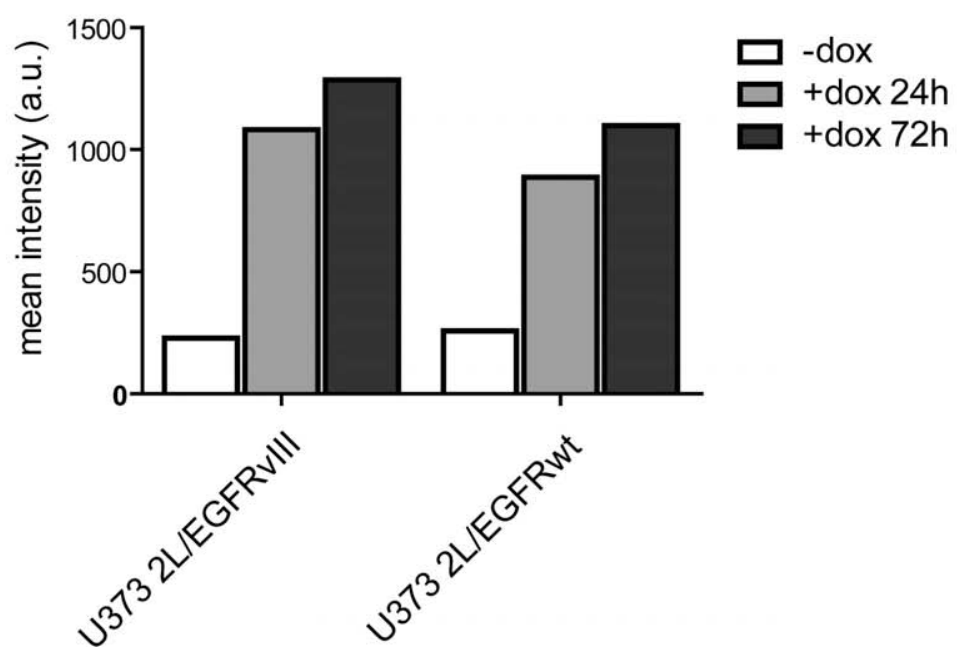

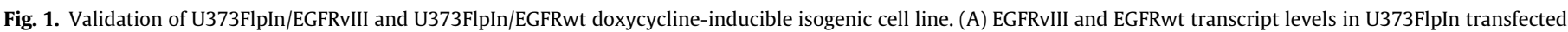

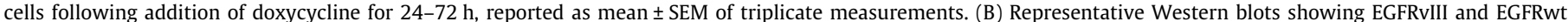

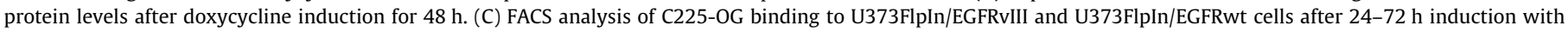
doxycycline.

was detected upon induction of the EGFRwt in U373FlpIn/EGFRwt (Fig. 2B). Similarly, overexpression of EGFRvIII resulted in significant induction of proliferation in conditions of low oxygen $(0.2 \%)$ (Fig. 2A, $p<0.05$ ) and complete anoxia (Fig. 2A, $p<0.05$ at $48 \mathrm{~h}$ ). Overexpression of EGFRwt did not lead to increased proliferation in either hypoxic or anoxic conditions (Fig. 2B), and remained at the same levels as the non-induced cells. No EGFRvIII-mediated growth promoting effect could be detected when cells were exposed to low glucose concentrations or when grown at pH 6.2 (data not shown).

To further address the biological significance of EGFRvIII overexpression, we performed cell survival assays. In conditions with low serum concentration, EGFRvIII-expressing cells survived significantly better as cells without EGFRvIII $(p<0.01$ at $2 \%$ and $p<0.05$ at $1 \%$, Fig. 3A). We have previously demonstrated that EGFRvIII expression promotes hypoxia tolerance [13]. However, those experiments were performed using cells that stably ex- pressed very high levels of EGFRvIII. We therefore also compared the hypoxia tolerance of the U373FlpIn/EGFRvIII and U373FlpIn/ EGFRwt cell lines following exposure to $48 \mathrm{~h}$ of hypoxia or anoxia. As shown in Fig. 3A, cells expressing EGFRvIII tolerated hypoxia $(p<0.05)$ and anoxia $(p<0.05)$ better than the cells that did not express the mutant receptor. Similar to our observations in proliferation experiments, overexpression of EGFRwt did not increase hypoxia or anoxia tolerance (Fig. 3B).

To investigate the influence of EGFRvIII expression on tumour growth in vivo, and to evaluate whether the observed in vitro observations could be translated to an effect in vivo, we injected U373FlpIn/EGFRvIII cells in NMRI-mice to form tumours. Mice were divided in two equal groups $(n=14)$ of which one received doxycycline. Cells in both groups formed tumours with similar efficiency and palpable tumours became visible at $\sim 12$ days postinjection. As illustrated in Fig. 4A, the tumours in animals that were given doxycycline grew significantly $(p<0.001)$ faster as 

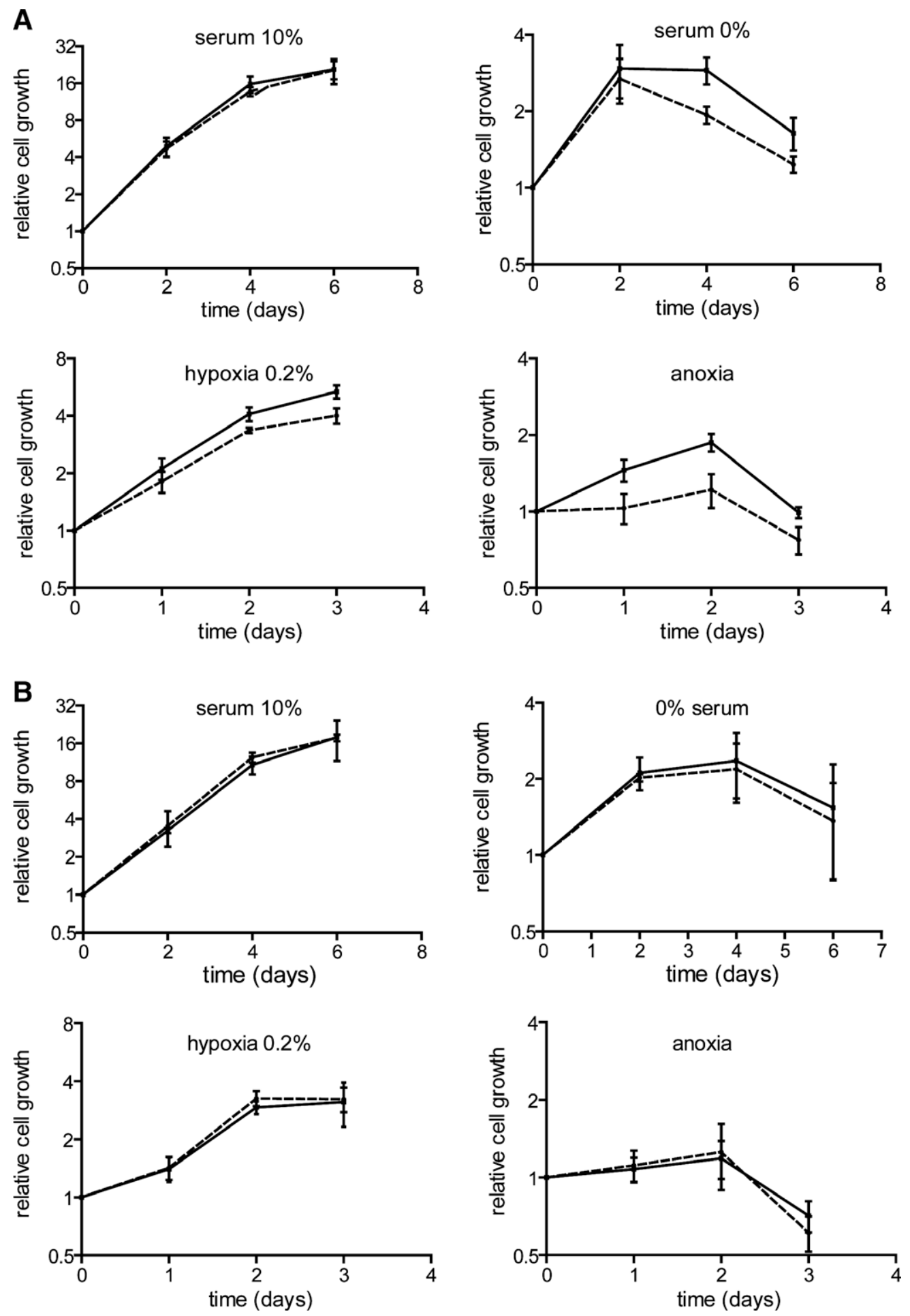

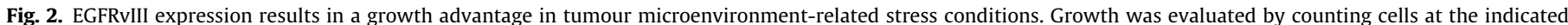

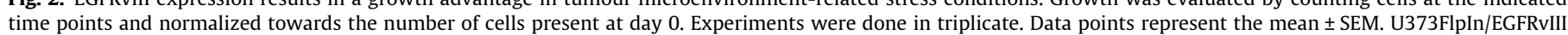
cells (A) and U373FlpIn/EGFRwt cells (B) were grown in the absence (dashed line) or presence (full line) of doxycycline at $10 \%$ or $0 \%$ serum, $0.2 \%$ hypoxia or in anoxia.

those in animals without doxycycline administration, as evidenced by the shorter doubling time of doxycycline-induced tumours versus the non-induced xenografts (9.3 days versus 10.7 days, $p<0.05$ ) (Fig. 4B). When tumours reached volumes of 250$400 \mathrm{~mm}^{3}$, animals from both groups $(n=6)$ were randomly switched to the other treatment group by withdrawing or administering doxycycline. Intriguingly, the tumour growth rate in ani- mals that were switched from no doxycycline to receiving doxycycline increased and their doubling time, calculated from the switch onwards, decreased (mean $T_{\mathrm{d}}=9.5$ days) to levels similar to that of tumours in which EGFRvIII was already expressed from the start of the experiment. Conversely, tumour growth rate in animals that were taken off doxycycline decreased, and doubling times (mean $T_{\mathrm{d}}=11.7$ days) became similar to those of tumours 
A

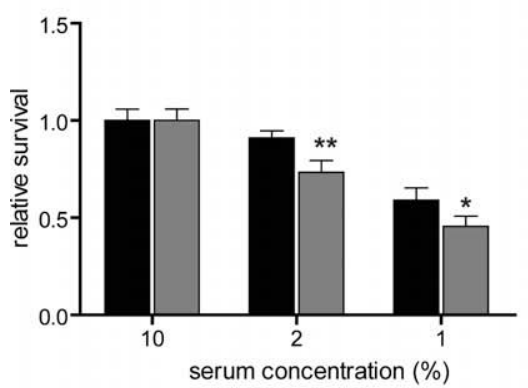

B

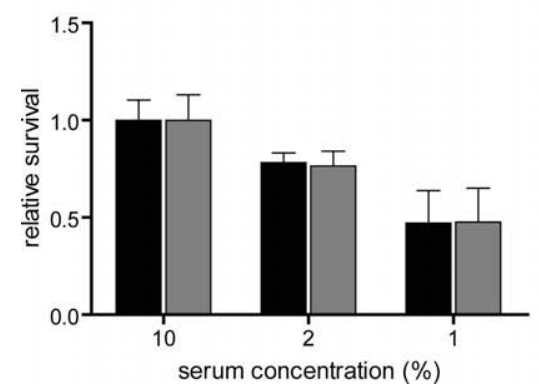

hypoxia $0.2 \%$

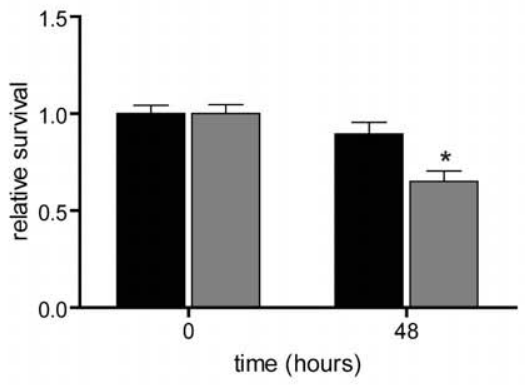

hypoxia $0.2 \%$

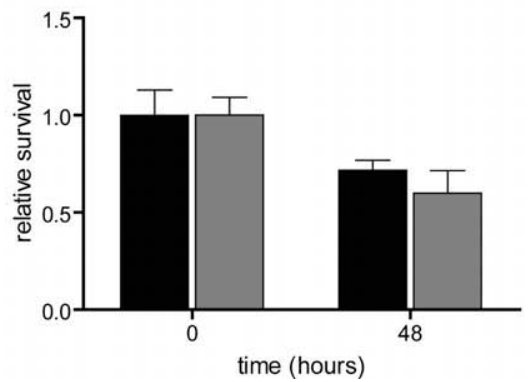

anoxia

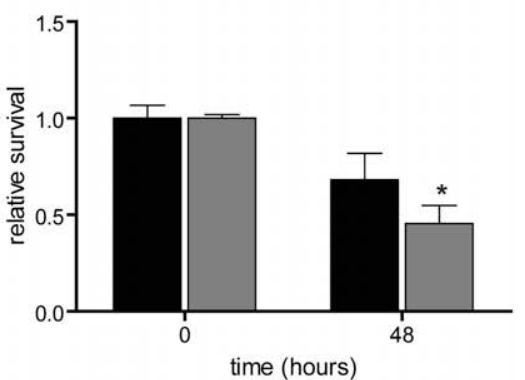

anoxia

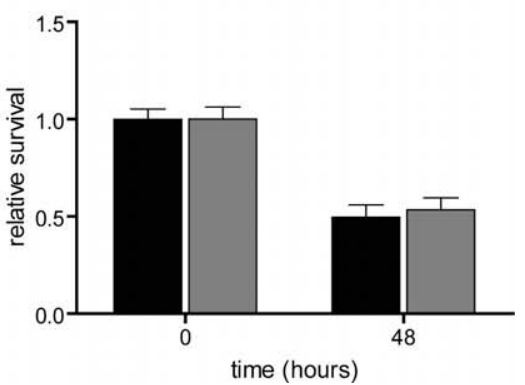

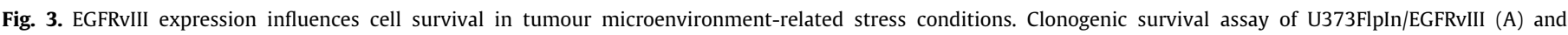

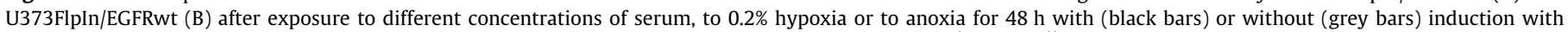
doxycycline. The mean values of three independent experiments are shown. Error bars represent SEM. $\left({ }^{*} p<0.05 ;{ }^{* * *} p<0.01\right)$.

that had never been induced with doxycycline (Fig. 4C). These data indicate that EGFRvIII promotes the growth of established tumours.

\section{Discussion}

In this study, we have shown that overexpression of EGFRvIII, but not of EGFRwt, results in a consistent proliferative and survival advantage when cells were grown under low serum, hypoxia or anoxia. Interestingly, the observed in vitro effects were also translated in increased rates of tumour growth in vivo. Previous reports have demonstrated a prominent role for EGFRvIII driving the progression of neoplastic events $[15,16]$. However, these studies have been mainly carried out using tumour models that massively and stably overexpress the mutant receptor. To rule out clonal effects of stable transfectants and to specifically investigate the tumourigenic role of EGFRvIII, we therefore developed an isogenic inducible system. Because several different transgenes can be inserted in an identical way into the same parental cell line, it is possible to compare their contribution and effectiveness in exactly the same genetic background, overcoming a general disadvantage of models used until now. Moreover, because EGFRvIII is constitutively active, an inducible model is particularly useful for studying such a mutant. Strikingly, whereas expression of the EGFRvIII-mutant confers proliferation and survival advantages in conditions of low serum and oxygen availability, overexpression of the wt receptor did not. This might be explained by the endogenous levels of wt receptor that are already present on these cells (Fig. 1C), masking the effects of a further increase of receptor expression. However, other mechanisms may explain the differential phenotypic effect we observed. EGFRvIII has been shown to be increasingly associated with the adapter proteins Shc and Grb2, and increased levels of the active form of Ras [17]. A recent large-scale analysis of phosphorylated proteins induced by EGFRvIII expression pointed towards PI3K signaling as the dominant pathway in glioblastoma cells [18]. The significance of this pathway has also been confirmed in other studies [19,20]. In a differential gene expression analysis, Ramnarain et al. revealed that expression of EGFRvIII resulted in specific upregulation of a small group of genes that are not induced by the wt receptor. These genes influence signaling pathways known to play a key role in oncogenesis and function in interconnected networks. Importantly, EGFRvIII but not EGFRwt plays an important role in generating an autocrine loop in glioma cells by increasing expression of ligands for the wt receptor [21]. The signaling potency of EGFRvIII might also be increased by its ability to signal for a prolonged time as a result of impaired endocytosis, inefficient ubiquitination and rapid recycling [22,23]. EGFRwt has been shown to be translationally upregulated under hypoxia [24]. In the stress conditions we have tested, however, this did not translate into a measurable phenotypic effect. Interestingly, we also observed an increase in EGFRvIII expression under hypoxia (unpublished observations). Although the underlying mechanism for the increased EGFRvIII levels is not yet clear, our data presented here suggest that this induction may contribute to the observed proliferative and survival advantage. In addition, this might lead to a selection of EGFRvIII-expressing cells in vivo, thereby contributing to the aggressive tumour phenotype. Interestingly, with the inducible model we have developed, tumours can be established with a parental genotype and subsequently induced to express a gene of interest to selectively examine its effect. The fact that tumours start to grow faster as soon as they are induced to express EGFRvIII (Fig. 4C), underscores the important role of EGFRvIII in the tumourigenesis process. Conversely, we also demonstrate that the increased growth rate of EGFRvIII-expressing tumours can be reversed when the mutant receptor is no longer expressed. These data indicate that targeting EGFRvIII by silencing its expression and/or blocking its downstream effects [25], even when EGFRwt receptor levels are relatively high as in our model, might be a promising strategy for treating cancers that contain this mutated receptor. 

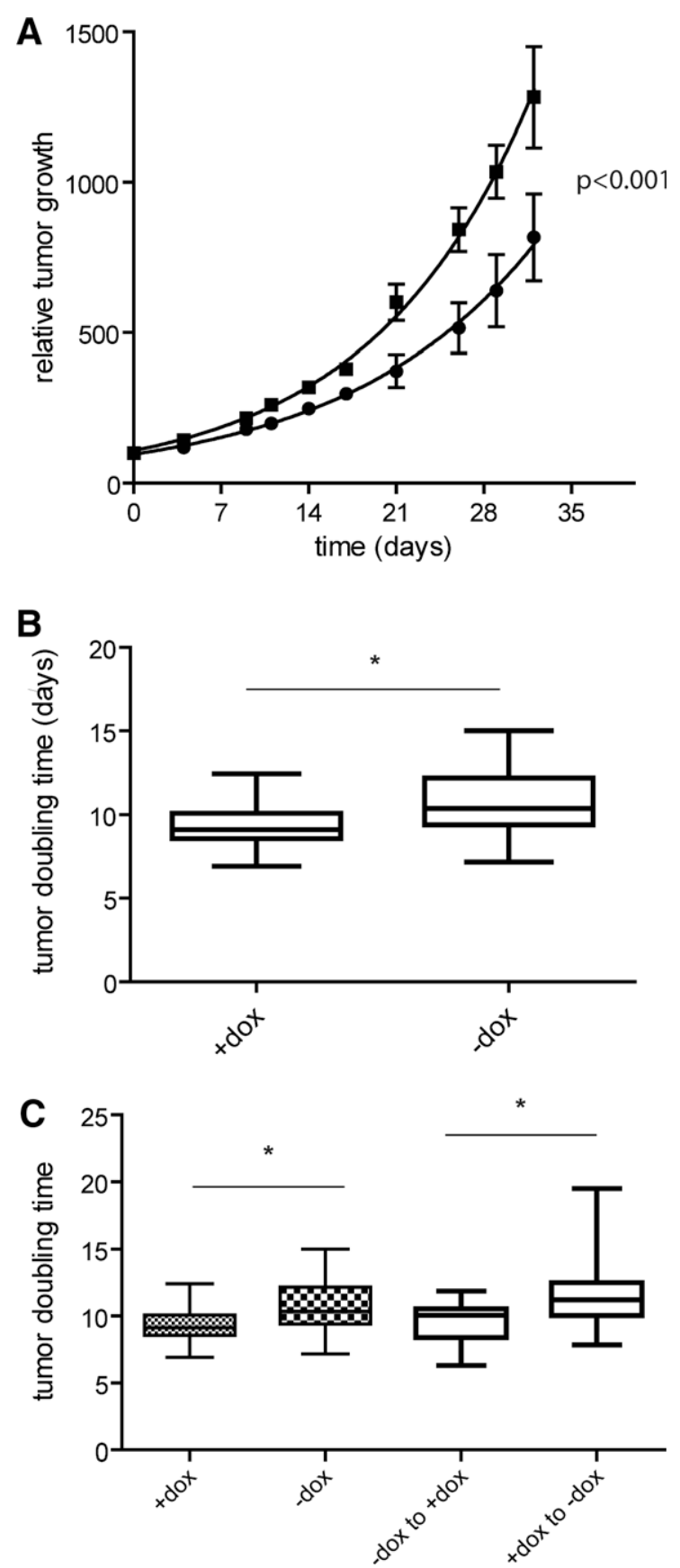

Fig. 4. Induction of EGFRvIII increases tumour growth in vivo. (A) U373FlpIn/ EGFRvIII xenografts were established in nude mice $(n=28)$. Mice were separated in two groups of which one group $(n=14)$ received doxycycline $(\mathbf{D})$ and the other group $(n=14)$ did not $(\bullet)$. Mean tumour volumes \pm SEM are shown. Volumes were normalized to the start of the measurements (day 0). Data were fitted using an exponential growth equation. Non-linear regression analysis was subsequently performed to compare whether both these fits are significantly different ( $F$-test). (B) Doubling times for tumours growing in animals that received doxycycline (left panel) or did not receive doxycycline (right panel) $\left({ }^{*} p<0.05\right)$. (C) Tumour doubling times in animals after switching of animals of both groups $(n=6)$ to the other treatment group by withdrawing or administering doxycycline $\left({ }^{*} p<0.05\right)$.

\section{Acknowledgements}

We acknowledge financial support from the Association for International Cancer research (AICR Grant 05-277 awarded to
G.L., P.L. and B.W.), the Dutch Cancer Society (KWF Grants UM 2006-3519 awarded to G.L., P.L. and B.W., UM 2008-4068 awarded to B.W. and 2008-4210 awarded to P.L., J.T. and B.W.) and to the EU 6th and 7th framework programme (EUROXY Grants 2003-502932 and METOXIA 2008-222741) awarded to P.L. and B.W.).

\section{References}

[1] Herbst RS. Review of epidermal growth factor receptor biology. Int J Radiat Oncol Biol Phys 2004;59:21-6.

[2] Bussink J, Kaanders JH, Van der Kogel AJ. Microenvironmental transformations by VEGF- and EGF-receptor inhibition and potential implications for responsiveness to radiotherapy. Radiother Oncol 2007;82:10-7.

[3] Hynes NE, Lane HA. ERBB receptors and cancer: the complexity of targeted inhibitors. Nat Rev Cancer 2005;5:341-54.

[4] Bonner JA, Harari PM, Giralt J, et al. Radiotherapy plus cetuximab for squamous-cell carcinoma of the head and neck. $\mathrm{N}$ Engl $\mathrm{J}$ Med 2006;354:567-78.

[5] Baumann M, Krause M, Dikomey E, et al. EGFR-targeted anti-cancer drugs in radiotherapy: preclinical evaluation of mechanisms. Radiother Oncol 2007;83:238-48.

[6] Lammering G. Molecular predictor and promising target: will EGFR now become a star in radiotherapy? Radiother Oncol 2005;74:89-91.

[7] Astsaturov I, Cohen RB, Harari PM. Clinical application of EGFR inhibitors in head and neck squamous cell cancer. Cancer Treat Res 2008;139:135-52.

[8] Krause M, Baumann M. Clinical biomarkers of kinase activity: examples from EGFR inhibition trials. Cancer Metastasis Rev 2008;27:387-402.

[9] Wong AJ, Ruppert JM, Bigner SH, et al. Structural alterations of the epidermal growth factor receptor gene in human gliomas. Proc Natl Acad Sci USA 1992;89:2965-9.

[10] Gan HK, Kaye AH, Luwor RB. The EGFRvIII variant in glioblastoma multiforme. J Clin Neurosci 2009.

[11] Bigner SH, Humphrey PA, Wong AJ, et al. Characterization of the epidermal growth factor receptor in human glioma cell lines and xenografts. Cancer Res 1990;50:8017-22.

[12] Wouters BG, Koritzinsky M. Hypoxia signalling through mTOR and the unfolded protein response in cancer. Nat Rev Cancer 2008;8:851-64.

[13] Weppler SA, Li Y, Dubois L, et al. Expression of EGFR variant vIII promotes both radiation resistance and hypoxia tolerance. Radiother Oncol 2007;83: 333-9.

[14] Aerts HJ, Dubois L, Hackeng TM, et al. Development and evaluation of a cetuximab-based imaging probe to target EGFR and EGFRvIII. Radiother Oncol 2007;83:326-32.

[15] Johns TG, Perera RM, Vernes SC, et al. The efficacy of epidermal growth factor receptor-specific antibodies against glioma xenografts is influenced by receptor levels, activation status, and heterodimerization. Clin Cancer Res 2007;13:1911-25.

[16] Tang CK, Gong XQ, Moscatello DK, Wong AJ, Lippman ME. Epidermal growth factor receptor vIII enhances tumorigenicity in human breast cancer. Cancer Res 2000;60:3081-7.

[17] Prigent SA, Nagane $\mathrm{M}$, Lin $\mathrm{H}$, et al. Enhanced tumorigenic behavior of glioblastoma cells expressing a truncated epidermal growth factor receptor is mediated through the Ras-Shc-Grb2 pathway. J Biol Chem 1996;271:25639-45.

[18] Huang PH, Mukasa A, Bonavia R, et al. Quantitative analysis of EGFRvIII cellular signaling networks reveals a combinatorial therapeutic strategy for glioblastoma. Proc Natl Acad Sci USA 2007;104:12867-72.

[19] Klingler-Hoffmann $M$, Bukczynska $P$, Tiganis T. Inhibition of phosphatidylinositol 3-kinase signaling negates the growth advantage imparted by a mutant epidermal growth factor receptor on human glioblastoma cells. Int J Cancer 2003;105:331-9.

[20] Narita Y, Nagane M, Mishima K, Huang HJ, Furnari FB, Cavenee WK. Mutant epidermal growth factor receptor signaling down-regulates p27 through activation of the phosphatidylinositol 3-kinase/Akt pathway in glioblastomas. Cancer Res 2002;62:6764-9.

[21] Ramnarain DB, Park S, Lee DY, et al. Differential gene expression analysis reveals generation of an autocrine loop by a mutant epidermal growth factor receptor in glioma cells. Cancer Res 2006;66:867-74.

[22] Grandal MV, Zandi R, Pedersen MW, Willumsen BM, van Deurs B, Poulsen HS EGFRvIII escapes down-regulation due to impaired internalization and sorting to lysosomes. Carcinogenesis 2007;28:1408-17.

[23] Wang Y, Roche O, Yan MS, et al. Regulation of endocytosis via the oxygensensing pathway. Nat Med 2009;15:319-24.

[24] Franovic A, Gunaratnam L, Smith K, Robert I, Patten D, Lee S. Translational upregulation of the EGFR by tumor hypoxia provides a nonmutational explanation for its overexpression in human cancer. Proc Natl Acad Sci USA 2007;104:13092-7.

[25] Lammering G, Hewit TH, Holmes M, et al. Inhibition of the type III epidermal growth factor receptor variant mutant receptor by dominant-negative EGFRCD533 enhances malignant glioma cell radiosensitivity. Clin Cancer Res 2004;10:6732-43. 